\title{
Defect in the Gene for MIS Type II Receptor
}

National Cancer Institute

\section{Source}

National Cancer Institute. Defect in the Gene for MIS Type // Receptor. NCI Thesaurus.

Code C120204.

A defect in the MISR II gene. 